\title{
Adenovirus Antibody Measurement
}

National Cancer Institute

\section{Source}

National Cancer Institute. Adenovirus Antibody Measurement. NCI Thesaurus. Code C111125.

The determination of the amount of adenovirus antibody present in a sample. 